\begin{tabular}{|c|l|}
\hline Title & Induction of triploidy by heat shock in the Japanese eel A nguillajaponica \\
\hline Author(s) & $\begin{array}{l}\text { Nomura, Kazuharu; Nakajima, Jun-ichiro; Ohta, Hiromi; Kagawa, Hirohiko; Tanaka, Hideki; Unuma, Tatsuya; } \\
\text { Y amauchi, Kohei; A rai, Katsutoshi }\end{array}$ \\
\hline Citation & $\begin{array}{l}\text { Fisheries Science, 70(2), 247-255 } \\
\text { https://doi.org/10.1111j.1444 2906.2003.00798.x }\end{array}$ \\
\hline Issue Date & 2004 \\
\hline Doc URL & http://hdl.handle.net/2115/35208 \\
\hline Rights & ○ 2004 公益社団法人日本水産学会; @ 2004 The Japanese Society of Fisheries Science \\
\hline Type & article \\
\hline File Information & arai-87.pdf \\
\hline
\end{tabular}

Instructions for use 


\title{
Induction of triploidy by heat shock in the Japanese eel Anguilla japonica
}

\author{
KazUHARU NOMURA, ${ }^{1 *}$ Jun-ICHIRo NAKAJIMA, ${ }^{2}$ Hiromi OHTA, ${ }^{3}$ Hirohiko KAGAWA, ${ }^{4}$
} HideKi TANAKA, ${ }^{1}$ TatsuYa UNUMA, ${ }^{1}$ KoHeI YAMAUCHI ${ }^{2}$ AND KaTsutoshi ARAI ${ }^{2}$

\begin{abstract}
${ }^{1}$ National Research Institute of Aquaculture, Nansei, Mie 516-0193, ${ }^{2}$ Graduate School of Fisheries Sciences, Hokkaido University, Hakodate, Hokkaido 041-8611, ${ }^{3}$ Faculty of Agriculture, Kinki University, Naka machi, Nara 631-8505 and ${ }^{4}$ Faculty of Agriculture, Miyazaki University, Miyazaki 889-2192, Japan
\end{abstract}

\begin{abstract}
Artificial reproduction and subsequent improved culture of the Japanese eel Anguilla japonica have not yet been achieved, but are expected in the near future. To allow the development of aquaculture activities, chromosome manipulation techniques are necessary for the genetic improvement of the eel. In the present paper suitable conditions were determined for heat shock treatment for the induction of triploidy. This was done using fertilized eggs obtained from gametes of cultured eels that were induced to mature by repeated injections of salmon pituitary extract, followed by an injection of $17 \alpha, 20 \beta$-dihydroxy-4-pregnen-3-one to induce ovulation in the female eels and by repeated injections of human chorionic gonadotropin in the male eels. Three variables (i.e. timing after fertilization, temperature, and duration of the shock) were varied to maximize the yield of triploid larvae by examining hatching and triploid rates of treated groups. Ploidy was determined by DNA content flow cytometry and/or chromosome counting. The triploid yield was the highest $(70 \%)$, when a $37^{\circ} \mathrm{C}$ heat shock was applied for $3 \mathrm{~min}, 10 \mathrm{~min}$ after fertilization. Under such conditions the rate of triploidy reached $70-100 \%$ and the rate of hatching was $5.2-24.6 \%$ when the control hatching rate was $28.5 \%$ on average.
\end{abstract}

KEY WORDS: Anguilla japonica, chromosome, flow cytometry, Japanese eel, triploid, heat shock.

\section{INTRODUCTION}

The Japanese eel Anguilla japonica is an important aquaculture species because of its high economic value, but artificial reproduction has not yet succeeded despite continuous efforts over three decades. ${ }^{1}$ Thus, at present the aquaculture of eels depends on catching wild elvers running to coastal estuaries. However, recently we have been able to obtain artificially matured eggs ${ }^{1}$ and spermatozoa ${ }^{2}$ using hormonal treatment, and viable leptocephali have been obtained due to the advancement of rearing techniques. ${ }^{3}$ If the perfect aquaculture cycle is determined, the program for genetic improvement will be one of the important subjects in the aquaculture practice of eels.

Chromosome set manipulation techniques have been developed and applied to the genetic improvement of various fish species over the past

\footnotetext{
*Corresponding author: Tel: 81-599-66-1830.

Fax: 81-599-66-1962. Email: nomurak@fra.affrc.go.jp

Received 7 July 2003. Accepted 17 November 2003.
}

few decades., ${ }^{4,5}$ Triploid female individuals are expected to have better growth, survival and meat quality than diploids during the period of final maturation, although such advantages of induced triploids have not yet been determined in marine species, mainly in freshwater fishes. ${ }^{5}$. Meiotic gynogenesis can be induced by using a combination of UV-irradiated spermatozoa and the same physical treatment as the triploidization (i.e. inhibition of the second polar body release), whereas mitotic gynogenesis producing completely homozygous gametes can be induced by inhibiting the first cleavage. These techniques may allow further development in the future improved aquaculture practices for eels. However, the treatment conditions leading to the duplication of the maternal genome in the Japanese eel have not yet been determined. Recently, chromosome manipulation techniques have been regarded as traditional ones, but they should not be viewed as obsolete methods because further advancement and improvement are predicted, particularly when they are integrated with other modern biotechnologies such as 
DNA marker mapping and micromanipulations of embryos. $^{5}$

In the present study we optimized the treating conditions of heat shock (timing after fertilization, temperature, and duration) in order to inhibit the second polar body release of fertilized eggs for the induction of triploidy. The ploidies of the offspring from the heat shock were determined by measuring the relative DNA content and/or counting the chromosome number. This is the first report of artificial triploids in the Japanese eel and may provide basic infrastructure to promote genetic and genomic studies using modern biotechnologies.

\section{MATERIALS AND METHODS}

\section{Artificial fertilization}

Artificially fertilized eggs were obtained from gametes of cultured eels induced to maturity by repeated injections of salmon pituitary extract, followed by an injection of $17 \alpha, 20 \beta$-dihydroxy-4pregnen-3-one (DHP) to induce ovulation in the female eels and by repeated injections of human chorionic gonadotropin (hCG) in the male eels. ${ }^{2,6}$ Approximately $20 \mathrm{~g}$ of eggs (3000-4000 eggs/g) were fertilized with $10 \mathrm{~mL}$ of sperm solution diluted 100-fold with artificial seminal plasma (149.3 mM NaCl, $15.2 \mathrm{mM} \mathrm{KCl}, 1.3 \mathrm{mM} \mathrm{CaCl}$, $1.6 \mathrm{mM} \mathrm{MgCl}_{2}, 20 \mathrm{mM} \mathrm{NaHCO}$ buffered with 20 mM N-tris(hydroxymethyl)methyl-3-aminepropanesulphonic acid (TAPS)-NaOH at $\mathrm{pH}$ 8.1; Ohta et $a l^{2}{ }^{2}$. The semen was activated by adding $50 \mathrm{~mL}$ of seawater that had been sterilized by filtration. Immediately, fertilized eggs were divided into experimental groups and then each group was placed in a glass vial containing $100 \mathrm{~mL}$ of seawater until heat shock. The water temperature during fertilization and before heat shock was maintained at $23^{\circ} \mathrm{C} \pm 1.0^{\circ} \mathrm{C}$.

\section{Experimental design}

After fertilization the eggs were gently transferred to a scoop net in the seawater by decantation. For the induction of triploidy, the scoop net keeping fertilized eggs was immersed in the preheated seawater to administer heat shock at the appropriate temperature, which was measured with a mercury thermometer (precision $\pm 0.1^{\circ} \mathrm{C}$ ) during the heat shock treatment. The temperature during the test period fluctuated at a range of $\pm 0.5^{\circ} \mathrm{C}$.

Three treatment variables for induction of triploidy were optimized: (i) time after fertilization (a.f) when the heat shock was initiated; (ii) temper- ature of the shock; and (iii) duration of the shock. Two experiments were carried out. Experiment 1 evaluated the suitable treatment timing after fertilization and temperature using eggs obtained from two female eels. Heat shock was applied for a duration of $3 \mathrm{~min}$ at temperatures of $30^{\circ} \mathrm{C}$ or $40^{\circ} \mathrm{C}$ at $1 \mathrm{~min}, 5 \mathrm{~min}$, and $10 \mathrm{~min}$ a.f. The control group consisted of intact fertilized eggs from gametes of the same parental fishes. The control was transferred to the incubator at the same time as the treated groups.

Experiment 2 investigated the effect of temperature and duration of the heat shock using eggs obtained from three female eels. Based on the results of experiment 1 , shocks were initiated $10 \mathrm{~min}$ a.f. The fertilized eggs were heat-shocked at $37^{\circ} \mathrm{C}$ or $39^{\circ} \mathrm{C}$ for a duration of $1 \mathrm{~min}$ or $3 \mathrm{~min}$. The control was maintained at the preshock temperature $\left(23^{\circ} \mathrm{C} \pm 1.0^{\circ} \mathrm{C}\right)$ and transferred to the incubator at $15 \mathrm{~min}$ a.f. After this, the water temperature was maintained at $23^{\circ} \mathrm{C} \pm 1.0^{\circ} \mathrm{C}$. Under this condition, hatching took place approximately $34-38 \mathrm{~h}$ a.f.

\section{Estimation of fertilization and hatching rate}

In experiments 1 and 2, approximately 100-200 fertilized eggs per group were transferred to $90 \mathrm{~mm}$ diameter plastic Petri dishes filled with $50 \mathrm{~mL}$ of seawater $\left(23^{\circ} \mathrm{C}\right)$. The seawater was then sterilized by filtration, after which streptomycin (final concentration $0.1 \mathrm{~g} / \mathrm{l}$, Meiji Seika, Japan) and penicillin $\mathrm{G}$ (final concentration $1 \times 10^{5}$ units/L, Banyu Pharmaceutical, Japan) were added, and then the Petri dishes containing the fertilized eggs were transferred to the incubator at $15 \mathrm{~min}$ a.f. Fertilization and hatching rates of these eggs were observed. The number of eggs in each dish was counted under a binocular microscope three times, and the mean value of the total number was calculated. The fertilization rate was calculated by counting the number of cleaved eggs at 4-6 h a.f., and unfertilized eggs were removed. Similarly, the hatching rate was calculated by counting the number of hatched larvae and non-hatched eggs at $40-42 \mathrm{~h}$ a.f.

\section{Flow cytometry}

In experiments 1 and 2 the larvae were sampled from each treatment group at 1 day after hatching (d.p.h) and fixed with 70\% ethanol and stored at $-20^{\circ} \mathrm{C}$ until analysis. Red blood cells from parental eels and sperm from male eels were fixed in the same manner. 
For measurement of the relative DNA content, flow cytometry (FCM) was conducted using a PA type flow cytometer (Partec, Germany). The method of FCM analysis followed the manufacturer's protocol with some modifications. Briefly, $10-20 \mu \mathrm{L}$ of cell suspensions prepared from fixed blood and sperm samples were re-suspended in $200 \mu \mathrm{L}$ of extraction buffer and were incubated for $15 \mathrm{~min}$ at room temperature. Subsequently, five volumes of 4',6-diamidino-2-phenylindole (DAPI) staining solution was added. The extraction buffer and the staining solution contained in the CyStain DNA 2 step high resolution DNA staining kit (Partec) were used. Larva was individually minced in $200 \mu \mathrm{L}$ of extraction buffer by using the tip of a pipette and incubated for $15 \mathrm{~min}$ at room temperature. The samples were then filtered through a $30 \mu \mathrm{m}$ mesh filter (Partec Cell Trics disposable filter units; Partec) and five volumes of staining solution were added. Ploidy was determined by the relative DNA content of somatic cells when erythrocytes of parental fishes were used as a standard of normal diploidy (2C).

\section{Chromosome preparation}

In experiment 2 the larvae were sampled from each treatment group at 1 d.p.h. They were moved into a plastic Petri dish (diameter: $90 \mathrm{~mm}$ ) filled with $0.002 \%$ colchicine (Wako Pure Chemical Industries, Japan) dissolved in sterilized seawater and incubated for $4 \mathrm{~h}$ at $23^{\circ} \mathrm{C}$. Subsequently, larvae were transfered into a $1.5 \mathrm{~mL}$ tube individually, centrifuged at $200 \times g$ for $10 \mathrm{~min}$ and the supernatant removed. Disodium citrate $(0.8 \%)$ was added for hypotonic treatment and samples were incubated for $30 \mathrm{~min}$ at $23^{\circ} \mathrm{C}$, and then larvae were fixed in two changes of fresh Carnoy's fixative (methanol : acetic acid, $3: 1$ ) and kept at $-20^{\circ} \mathrm{C}$ until use. Carnoy's solution was freshly made immediately before the preparation, then the fixed larva was minced and pipetted in $100 \mu \mathrm{L}$ of fresh Carnoy's solution. $20 \mu \mathrm{L}$ of the cell suspension was dropped onto a clean glass slide. After air drying the slides were stained with $4 \%$ Giemsa in phosphate buffer ( $\mathrm{pH}$ 6.8) for $10 \mathrm{~min}$. Chromosomes were counted and photographed for all well-spread metaphase cells. Because the chromosome number of diploid eel is reported as $2 \mathrm{n}=38,{ }^{7-9}$ we determined that larvae thathave 57 chromosomes are triploid, consisting of three sets of homologous chromosomes.

\section{Statistics}

Hatching and ploidy data were transformed to percentages. One-way analysis of variance (ANOVA) and Kruskal-Wallis ANOVA on ranks with Dunn's multiple comparison test were used to compare the treatment effects on hatching and triploid rate among groups, using computer software (InStat 2, GraphPad, USA). Differences were accepted as significant when $P<0.05$.

\section{RESULTS}

In experiment 1 all heat-shock groups were treated for 3 min duration (Table 1). There were no significant differences in the hatching rate between groups treated at the same time after fertilization but those at different temperatures had significant differences $(P>0.05$, ANOVA). Although groups treated at $30^{\circ} \mathrm{C}$ produced significantly higher hatching rates than those treated at $40^{\circ} \mathrm{C}$, there was no clear correlation between treatment timing and hatching rate (Table 1). Groups treated at $40^{\circ} \mathrm{C}$ had a nearly $0 \%$ hatching rate regardless of the timing. The FCM analysis determined that only the group treated with a $40^{\circ} \mathrm{C}$ heat shock at $10 \mathrm{~min}$ a.f. produced triploid larvae (Table 1; Fig. 1). The triploid rate was $80 \%(4 / 5)$. Triploidy was induced when the $40^{\circ} \mathrm{C}$ heat shock was applied for 3 min duration at 10 min a.f., but such a treatment gave an extremely low survival rate. Although $10 \mathrm{~min}$ a.f. was chosen as the optimal timing of the heat shock, the temperature and duration were further optimized in the next experiment.

Hatching rates in experiment 2 are shown in Table 2. There were no significant differences of the hatching rate among all treated groups, although hatching rates tended to decrease with the increase of temperature $\left(39^{\circ} \mathrm{C}\right)$. There was a significant difference in the rate of induced triploids between the $1 \mathrm{~min}$ and $3 \mathrm{~min}$ durations. Heat shocks at $37^{\circ} \mathrm{C}$ and $39^{\circ} \mathrm{C}$ for $3 \mathrm{~min}$ duration resulted in higher rates of triploids compared with those obtained by the 1 min treatments. Among treated groups, the $37^{\circ} \mathrm{C}$ heat shock for 3 min duration beginning at 10 min a.f. gave the best hatching rate (mean: $16.2 \%$, range: $5.2-24.6 \%$ ) as well as the best triploid rate (mean: $83.9 \%$, range: $70.4-100 \%$; Table 2). Diploid-triploid mosaics (Fig. 1) and a triploidtetraploid mosaic occurred more frequently in groups treated at $39^{\circ} \mathrm{C}$ than those treated at $37^{\circ} \mathrm{C}$ (Table 2). There were no significant differences in the fertilization rates among all groups including controls in experiments 1 and 2 (Tables 1,2).

Chromosome counting confirmed the occurrence of triploidy determined by FCM analysis (Table 3). Diploid eels in the control group had 38 chromosomes, consisting of 12 metacentric (m), eight submetacentric (sm) and 18 acrocentric (a) chromosomes (Fig. 2a,b). Such a karyo- 
Table 1 Hatching and triploid rates of heat shock groups from two females of the Japanese eel Anguilla japonica in experiment 1

\begin{tabular}{|c|c|c|c|c|c|c|c|c|c|c|c|c|c|c|c|c|c|}
\hline \multirow[b]{3}{*}{ Temp $\left({ }^{\circ} \mathrm{C}\right)$} & \multirow{3}{*}{$\begin{array}{l}\text { Timing } \\
\text { (min a.f.) }\end{array}$} & \multicolumn{6}{|c|}{ Female 1} & \multicolumn{6}{|c|}{ Female 2} & \multicolumn{4}{|c|}{ Mean } \\
\hline & & \multirow{2}{*}{$\begin{array}{l}\text { No. } \\
\text { eggs }^{\dagger}\end{array}$} & \multirow{2}{*}{$\begin{array}{c}\text { Fertilization } \\
(\%)\end{array}$} & \multirow{2}{*}{$\begin{array}{l}\text { Hatch } \\
(\%)\end{array}$} & \multirow{2}{*}{$\begin{array}{c}\text { No. } \\
\text { larvae }^{\ddagger}\end{array}$} & \multicolumn{2}{|c|}{$\begin{array}{l}\text { Ploidy } \\
(\%)^{\S}\end{array}$} & \multirow{2}{*}{$\begin{array}{l}\text { No. } \\
\text { eggs }^{\dagger}\end{array}$} & \multirow{2}{*}{$\begin{array}{c}\text { Fertilization } \\
\text { (\%) }\end{array}$} & \multirow{2}{*}{$\begin{array}{l}\text { Hatch } \\
(\%)\end{array}$} & \multirow{2}{*}{$\begin{array}{c}\text { No. } \\
\text { larvae }^{\ddagger}\end{array}$} & \multicolumn{2}{|c|}{$\begin{array}{l}\text { Ploidy } \\
(\%)^{\S}\end{array}$} & \multirow{2}{*}{$\begin{array}{c}\text { Fertilization } \\
(\%)\end{array}$} & \multirow{2}{*}{$\begin{array}{l}\text { Hatch } \\
(\%)\end{array}$} & \multicolumn{2}{|c|}{$\begin{array}{l}\text { Ploidy } \\
(\%)^{\S}\end{array}$} \\
\hline & & & & & & $2 n$ & $3 n$ & & & & & $2 n$ & $3 n$ & & & $2 n$ & $3 n$ \\
\hline Control & & 512 & 66.8 & 55.7 & 33 & 100.0 & 0.0 & 288 & 73.6 & 71.9 & 22 & 100.0 & 0.0 & 70.2 & 63.8 & 100.0 & 0.0 \\
\hline \multirow[t]{3}{*}{30} & 1 & 238 & 66.4 & 54.6 & 15 & 100.0 & 0.0 & 143 & 51.0 & 48.3 & 10 & 100.0 & 0.0 & 58.7 & 51.5 & 100.0 & 0.0 \\
\hline & 5 & 167 & 87.7 & 46.9 & 16 & 100.0 & 0.0 & 262 & 76.4 & 68.9 & 5 & 100.0 & 0.0 & 82.1 & 57.9 & 100.0 & 0.0 \\
\hline & 10 & 318 & 74.9 & 60.1 & 16 & 100.0 & 0.0 & 161 & 69.9 & 69.3 & 5 & 100.0 & 0.0 & 72.4 & 64.7 & 100.0 & 0.0 \\
\hline \multirow[t]{3}{*}{40} & 1 & 215 & 43.1 & 0.0 & - & - & - & 213 & 61.1 & 3.8 & - & - & - & 52.1 & 1.9 & - & - \\
\hline & 5 & 203 & 64.7 & $0.0^{\circ}$ & - & - & - & 163 & 65.7 & 0.0 & 3 & 100.0 & 0.0 & 65.2 & 0.0 & 100.0 & 0.0 \\
\hline & 10 & 304 & 52.6 & 0.0 & - & - & - & 249 & 54.2 & 0.0 & 5 & 20.0 & 80.0 & 53.4 & 0.0 & 20.0 & 80.0 \\
\hline
\end{tabular}

All treatments were applied for 3 min. a.f., after fertilization.

${ }^{\dagger}$ Hatching rate was estimated by total no. eggs.

${ }^{\ddagger}$ Total number of larvae (1 day after hatching) ploidies analysed by flow cytometry.

${ }^{\varsigma}$ Based on the relative DNA content measured by flow cytometry.
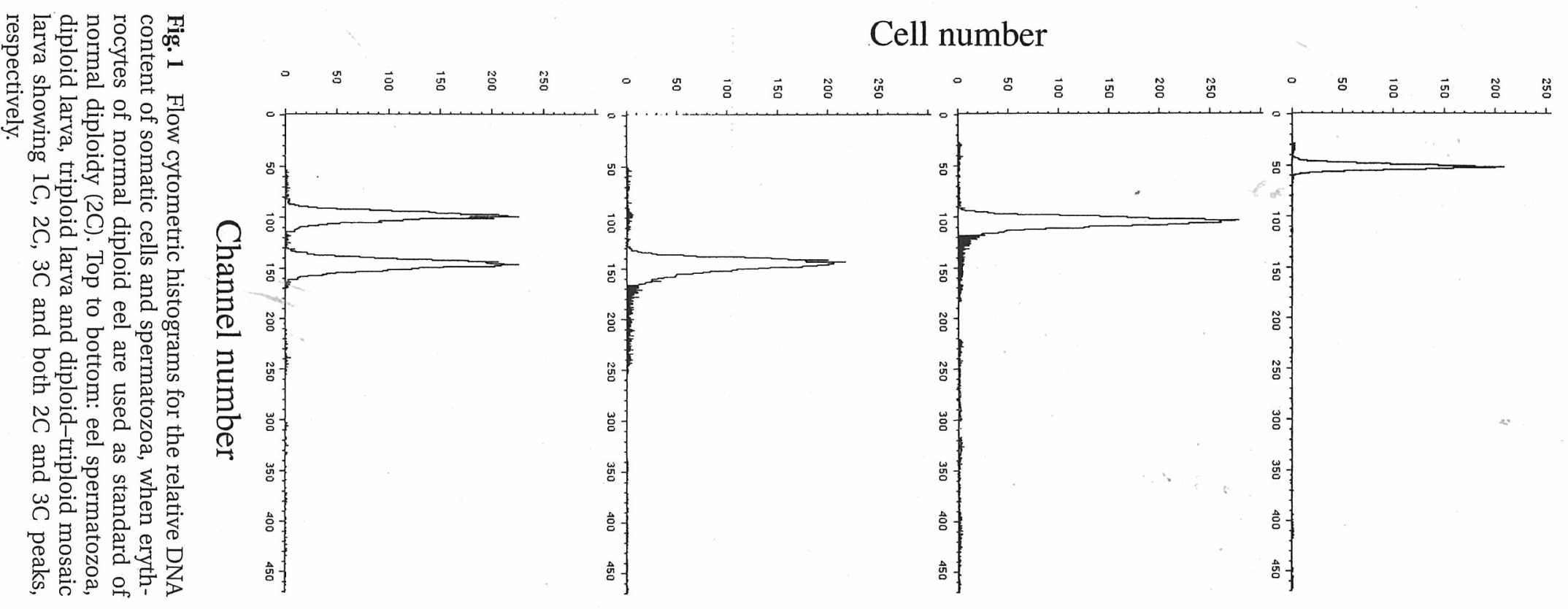


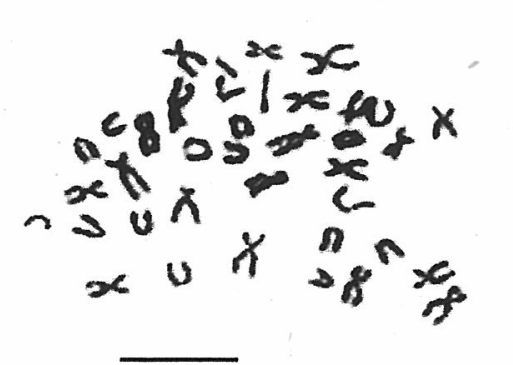

(a)

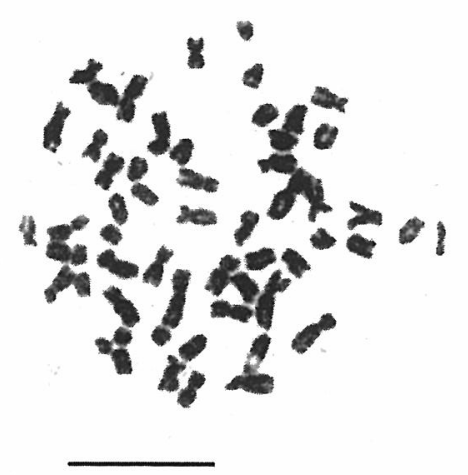

(c)

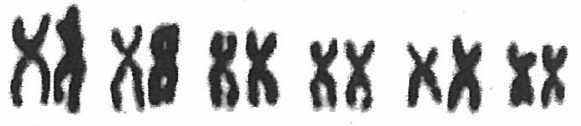 \\ $\mathrm{m}$

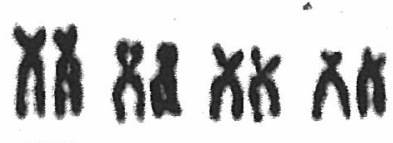 \\ sm}

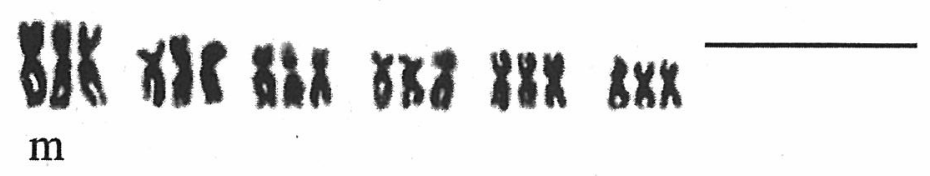

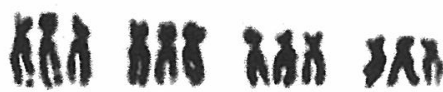 \\ $\mathrm{sm}$}

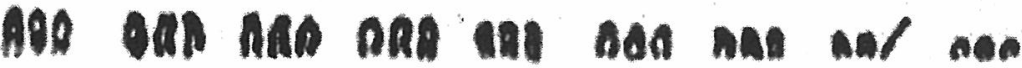

a

Fig. 2 Metaphases and karyotypes of the Japanese eel Anguilla japonica. (A) Diploid metaphase spread with 38 chromosomes; (B) diploid karyogram consisting of 12 metacentric (m), eight submetacentric (sm) and 18 acrocentric (a) chromosomes; (C) triploid metaphase spread with 57 chromosomes; (d) triploid karyogram consisting of 18 m, $12 \mathrm{sm}$ and $27 \mathrm{a}$. Bar $=10 \mu \mathrm{m}$.

type indicates diploidy with two sets of homologous chromosomes. In contrast, triploid eel induced by the heat shock had 57 chromosomes, consisting of $18 \mathrm{~m}, 12 \mathrm{sm}$ and $27 \mathrm{a}$ chromosomes (Fig. 2c,d). Such a karyotype indicates triploidy with three sets of homologous chromosomes. Diploid-triploid mosaic individuals were also observed in the treatment at $39^{\circ} \mathrm{C}$ for $3 \mathrm{~min}$ duration by the chromosome counting technique (Table 3 ).

Means of hatching rate of each heat-shock variable were compared to determine the appropriate range of temperature and duration of the heat shock. Table 4 shows the effect of each heat-shock variable on the hatching rate in experiments 1 and 2. The temperature of the shock was the most critical factor affecting hatchability among the three main variables in these experiments.

\section{DISCUSSION}

Although no studies have been done on the triploidization of any species of anguilliforms, Yamamoto and Yamauchi reported that the perivitelline space is formed at 20 min after fertilization at $23^{\circ} \mathrm{C}$ in the Japanese eel. ${ }^{10}$ Therefore, we predicted that the extrusion of the second polar body would occur before $20 \mathrm{~min}$ a.f. In the gilthead sea bream Sparus aurata, which also spawns pelagic eggs, triploid individuals were successfully induced when the heat shock was applied within 5 min a.f. ${ }^{11}$ Similarly, in several marine fish species examined, optimum timing for the retention of the second polar body release has been reported to be in the period between 0 and 15 min a.f. ${ }^{12}$

In experiment 1 , we optimized the timing of the heat shock $\left(30^{\circ} \mathrm{C}\right.$ or $40^{\circ} \mathrm{C}, 3$ min duration) 
Table 2 Hatching and triploid rates of heat shock groups from three female specimens of the Japanese eel Anguilla japonica in experiment 2

\begin{tabular}{|c|c|c|c|c|c|c|c|c|c|}
\hline \multirow[b]{2}{*}{ Female } & \multirow{2}{*}{$\begin{array}{l}\text { Temp } \\
\left({ }^{\circ} \mathrm{C}\right)\end{array}$} & \multirow{2}{*}{$\begin{array}{l}\text { Duration } \\
\text { (min) }\end{array}$} & \multirow{2}{*}{$\begin{array}{l}\text { No. } \\
\text { eggs }^{+}\end{array}$} & \multirow{2}{*}{$\begin{array}{l}\text { Fertilization } \\
(\%)\end{array}$} & \multirow{2}{*}{$\begin{array}{c}\text { Hatch } \\
(\%)\end{array}$} & \multirow{2}{*}{$\begin{array}{l}\text { No. } \\
\text { larvae }^{\ddagger}\end{array}$} & \multicolumn{3}{|c|}{ Ploidy $(\%)^{\ddagger}$} \\
\hline & & & & & & & $2 n$ & $3 n$ & Mosaic \\
\hline \multirow{5}{*}{3} & Control & & 92 & 60.4 & 37.0 & 32 & 100.0 & 0.0 & 0.0 \\
\hline & 37 & 1 & 143 & 59.3 & 4.9 & 27 & 63.0 & 37.0 & 0.0 \\
\hline & & 3 & 78 & 72.4 & 5.2 & 27 & 25.9 & 70.4 & $3.7^{\mathrm{a}}$ \\
\hline & 39 & 1 & 52 & 72.4 & 5.8 & 19 & 26.3 & 57.9 & $15.8^{\mathrm{b}}$ \\
\hline & & 3 & 85 & 57.5 & 0.0 & 26 & 7.7 & 69.2 & $23.1^{\mathrm{c}}$ \\
\hline \multirow[t]{5}{*}{4} & Control & & 125 & 65.9 & 35.2 & 26 & 100.0 & 0.0 & 0.0 \\
\hline & 37 & 1 & 149 & 71.5 & 13.5 & 21 & 100.0 & 0.0 & 0.0 \\
\hline & & 3 & 130 & 61.2 & 24.6 & 16 & 6.3 & 81.3 & $12.5^{\mathrm{d}}$ \\
\hline & 39 & 1 & 96 & 44.1 & 0.0 & 10 & 70.0 & 20.0 & $10.0^{\mathrm{e}}$ \\
\hline & & 3 & 90 & 50.9 & 8.9 & 12 & 0.0 & 66.7 & $33.3^{f}$ \\
\hline \multirow[t]{5}{*}{5} & Control & & 67 & 65.5 & 13.4 & 10 & 100.0 & 0.0 & 0.0 \\
\hline & 37 & 1 & 90 & 53.0 & 12.2 & 10 & 100.0 & 0.0 & 0.0 \\
\hline & & 3 & 95 & 49.8 & 18.9 & 10 & 0.0 & 100.0 & 0.0 \\
\hline & 39 & 1 & 67 & 53.7 & 11.9 & 10 & 40.0 & 50.0 & $10.0^{\mathrm{g}}$ \\
\hline & & 3 & 78 & 23.2 & 1.3 & 10 & 10.0 & 60.0 & $30.0^{\mathrm{h}}$ \\
\hline \multirow[t]{5}{*}{ Mean } & Control & & 95 & 63.9 & 28.5 & 23 & 100.0 & 0.0 & 0.0 \\
\hline & 37 & 1 & 127 & 61.3 & 10.2 & 19 & 87.7 & 12.3 & 0.0 \\
\hline & & 3 & 101 & 61.1 & 16.2 & 18 & 10.7 & 83.9 & 5.4 \\
\hline & 39 & 1 & 72 & 56.7 & 5.9 & 13 & 45.4 & 42.6 & 11.9 \\
\hline & & 3 & 84 & 43.9 & 3.4 & 16 & 5.9 & 65.3 & 28.8 \\
\hline
\end{tabular}

All treatments were applied at 10 min after fertilization.

${ }^{\dagger}$ Hatching rate was estimated by total no. eggs.

¥ Total number of larvae ( 1 day after hatching) ploidies analysed by flow cytometry.

${ }^{\ddagger}$ Based on relative DNA content measured by flow cytometry.

Observed cell types of mosaic individuals ${ }^{2} 2 n / 3 n, 1 ;{ }^{b} 2 n / 3 n, 3 ;{ }^{c} 2 n / 3 n, 5 ; 3 n / 4 n, 1 ;{ }^{d} 2 n / 3 n, 2 ;{ }^{e} 2 n / 3 n, 1 ;{ }^{\mathrm{f}} 2 n / 3 n, 4 ;{ }^{2} 2 n / 3 n, 1 ;{ }^{\mathrm{h}} 2 n / 3 n, 3$.

starting at $1 \mathrm{~min}, 5 \mathrm{~min}$, and $10 \mathrm{~min}$ a.f. by examining the hatching and triploid rates, and triploidy was successfully induced only in the treatment initiated at $10 \mathrm{~min}$ a.f. The heat-shock groups treated at $30^{\circ} \mathrm{C}$ produced a high hatching rate but failed to induce triploidy. In contrast, those treated at $40^{\circ} \mathrm{C}$ had an $80 \%$ triploid rate in spite of very poor hatching. Because embryos could not survive after the heat shock at $40^{\circ} \mathrm{C}$, we examined the effect of a slightly lower temperature in experiment 2. Then, we concluded that the optimum triploidization condition for Japanese eel eggs incubated at $23^{\circ} \mathrm{C}$ was a heat shock at $37^{\circ} \mathrm{C}$ for $3 \mathrm{~min}$ duration, beginning $10 \mathrm{~min}$ a.f. Such conditions gave the best hatching and triploid rates. In the heat shock at $39^{\circ} \mathrm{C}$ for $3 \mathrm{~min}$ duration, beginning at the same time, both hatching and triploid rates were reduced. Because temperature is the most critical variable of heat shock on the hatching rate of treated embryos, we expected a better hatching rate at a heat shock with a temperature lower than $37^{\circ} \mathrm{C}$. As mentioned here, further improvement of conditions to induce triploids is possible. However, we could not make further systematic optimization because there was a technical limitation to col- lecting a high enough volume of good quality gametes for different experiments. Further detailed investigation is required to examine the effect of lower temperature and longer duration of the heat shock in order to realize a $100 \%$ triploid population.

Induced triploids were shown to have three sets of homologs by DNA content flow cytometry as well as karyotyping. Heat-shock groups basically consisted of triploid and misinduced diploid individuals. In addition, we found mosaic individuals in the heat shock groups not only by chromosome counting but also by flow cytometry. The occurrence of mosaicisms was more frequent in the group treated at $39^{\circ} \mathrm{C}$ than that treated at $37^{\circ} \mathrm{C}$. If these mosaics are caused by inappropriate heat-shock treatment, absence of mosaicisms suggests the success of heat shock. Thus, we also determined the appropriate conditions for induced triploidy from the absence of mosaics in the heat-shock group. It has been reported that mosaicism occurs at a relatively low frequency when inadequate physical treatment is applied for duplication of chromosomes. ${ }^{5,13,14}$ Even then, the cause of the mosaicism must be examined in detail, and further investigation of the physical 
Table 3 Chromosome numbers of larvae from heat shock groups of female 4 of the Japanese eel Anguilla japonica in experiment 2

\begin{tabular}{|c|c|c|c|c|c|c|c|c|c|c|c|c|c|c|c|c|c|c|c|c|c|c|c|c|c|c|c|c|c|c|c|c|}
\hline \multirow[b]{2}{*}{ Temp ${ }^{\circ} \mathrm{C}$} & \multirow{2}{*}{$\begin{array}{l}\text { Duration } \\
\text { (min) }\end{array}$} & \multirow{2}{*}{$\begin{array}{c}\text { Embryo } \\
\text { no. }\end{array}$} & \multicolumn{29}{|c|}{ No. chromosomes } & \multirow{2}{*}{$\begin{array}{l}\text { Total no. } \\
\text { cells counted }\end{array}$} \\
\hline & & & 33 & 34 & 35 & $36^{*}$ & 37 & 38 & 39 & 40 & 41 & 42 & 43 & 44 & 45 & 46 & 47 & 48 & 49 & 50 & 51 & 52 & 53 & 54 & 55 & 56 & 57 & 58 & 59 & 606 & $\overline{61}$ & \\
\hline \multirow{5}{*}{ Control } & & 1 & & & 1 & 2 & 2 & 10 & & & & & & & & & & & & & & & & & & & & & & & & 15 \\
\hline & & 2 & & 1 & 1 & 1 & 3 & 11 & & & & & & & & & & & & & & & & & & & & & $>$ & & & 17 \\
\hline & & 3 & & & & 2 & 2 & 7 & & & & & & & & & & & & & & & & & & & & & & & & 11 \\
\hline & & 4 & & 1 & 1 & 3 & 2 & 8 & & & & & & & & & & & & & & & & & & & & & & & & 15 \\
\hline & & 5 & 1 & 1 & 1 & 2 & 1 & 6 & & & & & & & & & & & & & & & & & & & & & & & & 12 \\
\hline \multirow[t]{10}{*}{37} & 1 & 1 & 1 & 2 & & & & 18 & & & & & & & & & & & & & & & & & & & & & & & & 21 \\
\hline & & 2 & & & & 3 & 3 & 44 & & & & & & & & & & & & & & & & & & & & & & & & 50 \\
\hline & & 3 & & 1 & 1 & 1 & 2 & 15 & & & & & & & & & & & & & & & & & & & & & & & & 20 \\
\hline & & 4 & & 1 & 2 & 2 & 2 & 52 & & & & & & & & & & & & & & & & & & & & & & & & 59 \\
\hline & & 5 & & & 1 & 1 & 3 & 16 & & & & & & & & & & & & & & & & & & & & & & & & . 21 \\
\hline & 3 & 1 & & & & & & & & & & & & & & & 1 & & & & 2 & 2 & 2 & 1 & & 1 & 20 & & & & & 29 \\
\hline & & 2 & & & & & & & & & & & & & & & & & & & 1 & & 1 & & & & 17 & & & & & 19 \\
\hline & & 3 & & & & & & & & & & & & & & & & & 1 & 1 & & & 3 & 2 & 1 & 1 & 14 & & & & & 23 \\
\hline & & 4 & & & & 1 & 3 & 12 & & & & & & & & & & & & & & & & & & & & & $\gamma$ & & & 16 \\
\hline & & 5 & & & & & & & & & & & & & & & 1 & & & & & & 2 & 1 & 1 & 2 & 11 & & & & & 18 \\
\hline \multirow[t]{5}{*}{39} & 3 & 1 & & & & & & & & & & & & & & & & & & & & & & & & & 1 & & & & & 1 \\
\hline & & 2 & & & & & & & & & & & & & & & & 1 & & 2 & 1 & 3 & 1 & & & 1 & 9 & & & & & 18 \\
\hline & & 3 & & & & 1 & 1 & 9 & & & & & & & & & & 1 & & & & & & & & & 3 & & & & & 15 \\
\hline & & 4 & & & & & & & & & & & & & & 1 & & & & & & 1 & 1 & 1 & . & 1 & 6 & 6 of & & & & 11 \\
\hline & & 5 & & & & & & & & & 1 & & & & 1 & & 1 & & & & & 1 & & & & 1 & 2 & & & & & 7 \\
\hline
\end{tabular}


Table 4 Effect of variables of heat shock on the hatching rate of the Japanese eel calculated as a percentage of the control

\begin{tabular}{lc}
\hline Main variable of heat shock & Hatching rate (\%) \\
\hline Timing (min a.f.) & \\
1 & $42.62^{\mathrm{a}}$ \\
5 & $45.01^{\mathrm{a}}$ \\
10 & $44.46^{\mathrm{a}}$ \\
Temp $\left({ }^{\circ} \mathrm{C}\right)$ & \\
30 & $91.59^{\mathrm{a}}$ \\
37 & $61.27^{\mathrm{a}}$ \\
39 & $23.25^{\mathrm{ab}}$ \\
40 & $0.88^{\mathrm{b}}$ \\
Duration (min) & \\
1 & $41.18^{\mathrm{a}}$ \\
3 & $45.27^{\mathrm{a}}$ \\
\hline
\end{tabular}

a.f., after fertilization.

Different superscripts in the same category indicate significant difference $(P<0.05)$. '

treatment conditions is needed in order to produce a $0 \%$ mosaic individual rate in the heatshock group.

Chromosome set manipulation techniques are useful not only for the improvement of commercially important traits for aquaculture, but also for the production of reference families for basic genetic studies. Using triploids or meiotic diploids, map distance between a given locus and centromere of a chromosome can be easily estimated by the second meiotic division segregation frequency $(y) .{ }^{15}$ Such an estimation of the gene (marker)-centromere recombination rate has been studied in several fishes using hypervariable genetic markers including microsatellites. ${ }^{15-18}$ The map distance in relation to the centromere may be applied to calibrate the linkage map distances showing relationships between different loci. Integration of gene (marker)-centromere map and linkage map will satisfy an essential requisite not only for elucidating genetic syntenies among different species but also for identification of commercially important quantitative traits in aquaculture species. For future marker-assisted selection (MAS) aiming at genetic improvement of eel strains for aquaculture, genetic mapping using chromosomally manipulated fishes is important. We have developed a technique for triploidization of the eel but further studies are necessary for the production of gynogenetic or androgenetic diploids as well as for the development of DNA markers. The induction of triploidy is the first step toward such areas of genetic and genomic studies of this species.

\section{ACKNOWLEDGMENTS}

We thank Dr A Fujiwara, T Suzuki and N Hattori for their assistance in the present study. This work was supported in part by the special Grants-in-Aid in the 1999 and 2000 fiscal years to KA from the president of Hokkaido University.

\section{REFERENCES}

1. Kagawa $\mathrm{H}$, Ohta $\mathrm{H}$, Tanaka $\mathrm{H}$. Recent progress of research on larvae production of Japanese eel, Anguilla japonica. Suisanzoshoku 2001; 49: 127-132.

2. Ohta $\mathrm{H}$, Tanaka $\mathrm{H}$, Kagawa $\mathrm{H}$, Okuzawa $\mathrm{K}$, Iinuma $\mathrm{N}$. Artificial fertilization using testicular spermatozoa in the Japanese eel Anguilla japonica. Fish. Sci. 1997; 63: 393396.

3. Tanaka H, Kagawa H, Ohata H. Production of leptocephali of Japanese eel (Anguilla japonica) in captivity. Aquaculture 2001; 201: 51-60.

4. Pandian TJ, Koteeswaran R. Ploidy induction and sex control in fish. Hydrobiologia 1998; 384: 167-243.

5. Arai K. Genetic improvement of aquaculture finfish species by chromosome manipulation techniques in Japan. Aquaculture 2001; 197: 205-228.

6. Kagawa $\mathrm{H}$, Tanaka $\mathrm{H}$, Ohta $\mathrm{H}$, Okuzawa $\mathrm{K}$, Iinuma $\mathrm{N}$. Induced ovulation by injection of $17,20 \beta$-dihydroxy-4pregnen-3-one in the artificially matured Japanese eel, with special reference to ovulation time. Fish. Sci. 1997; 63: 365367.

7. Nishikawa S, Amaoka K, Kawasawa T. On the chromosomes of two species of eels. Chrom. Infor. Serv. 1971; 12: $27-28$.

8. Park EH, Kang YS. Karyological confirmation of conspicuous ZW sex chromosomes in two species of Pacific anguillloid fishes (Anguilliforms: Teleostomi). Cytogenet. Cell Genet. 1979; 23: 33-38.

9. Fujiwara A, Nishida-Umehara C, Sakamoto T, Okamoto N, Nakayama I, Abe S. Improved fish lymphocyte culture for chromosome preparation. Genetica 2001; 111: 77-89.

10. Yamamoto K, Yamauchi K. Sexual maturation of Japanese eel and production of eel larvae in the aquarium. Nature 1974; 251: 220-222.

11. Garrido-Ramos M, De la Harran R., Lozano R., Cardenas S, Ruiz Rejon C, Ruiz Rejon M. Induction of triploidy in offsprings of gilthead seabream (Sparus aurata) by means of heat shock. J. Appl. Ichthyol. 1996; 12: 53-55.

12. Felip A, Zanuy S, Carrillo M, Piferrer F. Induction of triploidy and gynogenesis in teleost fish with emphasis on marine species. Genetica 2001; 111: 175-195.

13. Miller GD, Seeb JE, Bue BG, Sharr S. Saltwater exposure at fertilization induces ploidy alterations, including mosaicism, in salmonids. Can. J. Fish. Aquat. Sci. 1994; 51: 42-49.

14. Teplitz RL, Joyce JE, Doroshov SI, Min BH. A preliminary ploidy analysis of diploid and triploid salmonids. Can. J. Fish. Aquat. Sci. 1994; 51: 38-41.

15. Thorgaard GH, Allendorf FW, Knudsen KL. Genecentromere mapping in rainbow trout: high interference over long map distance. Genetics 1983; 103: 771-783. 
16. Guyomard R. High level of residual heterozygosity in gynogenetic rainbow trout, Salmo gairdneri, Richardson. Theor. Appl. Genet. 1984; 67: 307-316.

17. Estoup A, Presa P, Krieg F, Vaiman D, Guyomard R. (CT) and $(\mathrm{GT})_{\mathrm{n}}$ microsatellites: a new class of genetic markers for Salmo trutta L. (brown trout). Heredity 1993; 71: 488496.

18. Morishima K, Nakayama I, Arai K. Microsatellitecentromere mapping in the loach, Misgurnus anguillicaudatus. Genetica 2001; 111: 59-69. 